\title{
ARTIKELEN
}

\section{Regionale verschillen in duurzame inzetbaarheid}

\author{
Oleg Boneschansker \& John Klein Hesselink
}

Duurzame inzetbaarheid van werkenden is het vermogen om gezond, vitaal en productief deel te nemen aan betaalde arbeid tot de pensioengerechtigde leeftijd. Het bevorderen van gezondheid, scholing en mobiliteit en het beperken van uitval zijn hiertoe belangrijke voorwaarden. Beleidsmakers streven ernaar duurzame inzetbaarheid te vergroten om de concurrentiekracht van de Nederlandse economie te laten groeien en om werkloosheid ten gevolge van uitval, vroegtijdig pensioen en een in gebreke zijnde mobiliteit te verkleinen. Duurzame inzetbaarheid bestaat uit een aantal kenmerken. Op basis van de Nationale Enquête Arbeidsomstandigheden (NEA) en de Werkgevers Enquete Arbeid (WEA) is een duurzame inzetbaarheidsprofiel samengesteld dat het concept tracht te vangen in zeventien kenmerken. Deze onderzoeksnotitie laat zien dat deze kenmerken regionale verschillen vertonen en dat deze verschillen tot op zekere hoogte verklaard worden door regionale kenmerken. Op basis van deze bevindingen worden een aantal onderzoekssuggesties aangedragen voor de ontwikkeling van regionaal georiënteerd beleid.

\section{Is duurzame inzetbaarheid een regionale aangelegenheid?}

Duurzame inzetbaarheid van werkenden is het vermogen om gezond, vitaal en productief deel te nemen aan betaalde arbeid tot de pensioengerechtigde leeftijd (Hooftman et al., 2012). Het bevorderen van gezondheid, scholing en mobiliteit en het beperken van uitval zijn hiertoe belangrijke voorwaarden, stellen de minister en staatssecretaris van het ministerie van Sociale Zaken en Werkgelegenheid (SZW) in hun de brief aan de Tweede Kamer (AV/SDA/2012/12049). Duurzame inzetbaarheid is volgens deze brief sociaal wenselijk en economisch noodzakelijk. Sociaal wenselijk omdat te veel mensen de pensioenleeftijd niet werkend halen of op een te grote afstand van de arbeidsmarkt komen te staan. Economisch omdat langer doorwerken nodig is voor het behoud van de concurrentiepositie van Nederland op de wereldmarkt en het betaalbaar houden van de pensioenen, de AOW en de sociale zekerheid.

Duurzame inzetbaarheid is daarom direct gerelateerd aan een toename van arbeidscapaciteit in de bedrijven, een hogere bijdrage aan het nationaal inkomen en een hogere arbeidsparticipatie. Inmiddels is het ministerie van SZW gestart met een project om duurzame inzetbaarheid hoog op de agenda te zetten bij werkgevers en werknemers. Samen met honderd werkgevers die actief zijn op het

* Oleg Boneschansker is werkzaam bij de Universiteit Utrecht, School of Economics. Email: o.v.boneschansker@uu.nl. John Klein Hesselink was werkzaam bij TNO Work \& Health en is gepensioneerd. 
gebied van duurzame inzetbaarheid, is vervolgens het 'manifest duurzame inzetbaarheid' opgesteld (www.duurzameinzetbaarheid.nl). In een brief van de minister en staatssecretaris van het ministerie van SZW aan de Tweede Kamer (ASEA/ SAS/2012/15124) stellen zij voor om werkgevers en werknemers te stimuleren en te faciliteren om zelf met duurzame inzetbaarheid aan de slag te gaan. Dit is conform het beleid van het ministerie dat erop gericht is dat werkgevers en werknemers zelf verantwoordelijk zijn voor het optimaliseren van de werksituatie. Het project heeft als doel hen daarbij te ondersteunen met kennis en praktijkervaring. Werkgevers en werknemers zijn dus primair verantwoordelijk voor het bevorderen van duurzame inzetbaarheid en het beperken van uitval. Indien zij hun verantwoordelijkheden niet nemen, komen de consequenties van het achterwege blijven op conto van de gehele Nederlandse samenleving. Als werknemers vanwege gezondheidsproblemen of veroudering van competenties niet langer in staat zijn te participeren op de arbeidsmarkt, vallen zij immers terug op collectieve fondsen en middelen uit bijvoorbeeld de WIA, WW en WWB. Onvoldoende duurzame inzetbaarheid vormt daarmee een maatschappelijk probleem, mede omdat steeds minder werkenden betalen voor steeds meer niet-werkenden. De verantwoordelijkheid voor het oplossen van een te lage arbeidsparticipatie, waarvan de uitvoering in toenemende mate op regionaal niveau plaatsvindt, ligt voor een groot gedeelte bij gemeenten en UWV (Inspectie SZW, 2013). De bevordering van duurzame inzetbaarheid is daarmee ook een regionaal thema. Om het gemeenten en UWV mogelijk te maken om doelmatig regionaal beleid te voeren is het van belang om te onderzoeken of er regionale verschillen zijn in duurzame inzetbaarheid en indien er verschillen zijn, deze te verklaren. Dit biedt gemeenten en UWV de mogelijkheid om in de uitvoering van hun beleid gericht in te spelen op regiospecifieke kenmerken.

\section{Wat is duurzame inzetbaarheid en hoe is het te meten?}

Hoewel doorwerken tot de pensioengerechtigde leeftijd centraal staat binnen het concept duurzame inzetbaarheid, is het een containerbegrip dat uit veel meer kenmerken bestaat (Hooftman et al., 2012). Voor het meten van duurzame inzetbaarheid moeten dus meerdere kenmerken worden gemeten. Daarom ligt het voor de hand om een profiel samen te stellen, een DI-profiel, waarin de verschillende kenmerken van duurzame inzetbaarheid overzichtelijk staan weergegeven. Kraan et al. (2011) hebben zo'n profiel ontwikkeld op basis van gegevens van landelijk representatief onderzoek onder werknemers en werkgevers. Hiertoe selecteerden zij zeventien indicatoren, die zijn weergegeven in figuur 1 . Twaalf van de zeventien indicatoren zijn gemeten met de Nationale Enquête Arbeidsomstandigheden (NEA) 2012 van TNO en het Centraal Bureau voor de Statistiek, die is ingevuld door ruim 25.000 werknemers (Koppes et al., 2013). Van deze twaalf indicatoren staan het willen en kunnen doorwerken tot een bepaalde leeftijd centraal. Daarnaast bestaan deze uit psychosociale en fysieke werkkenmerken, ontwikkelingskenmerken en arbeidsmarktperspectieven van werknemers. De overige vijf indicatoren zijn ontleend aan de Werkgevers Enquête Arbeid (WEA) 2012 van 


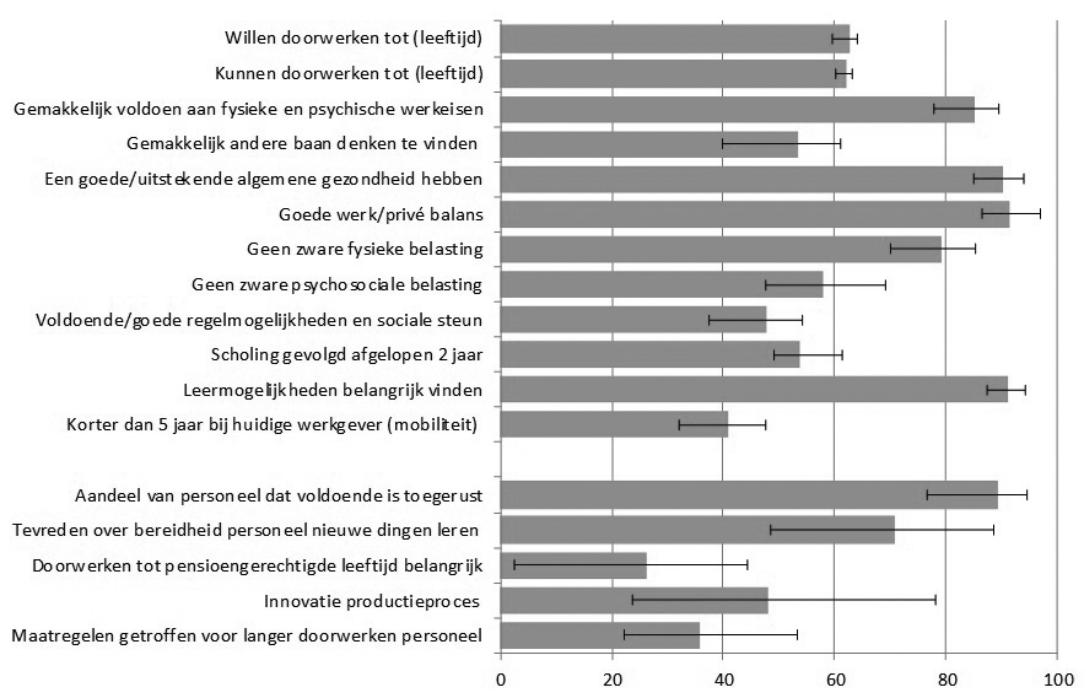

Figur 1 Referentiewaarden (gemiddelde, hoogste en laagste waarde) van de DI-indicatoren van de COROP-regio's (bron: NEA 2012 (eerste twaalf indicatoren), WEA 2012 (laatste vijf indicatoren))

TNO, waarop ruim 5000 werkgevers hebben gerespondeerd (Oeij et al., 2013). Deze indicatoren omvatten gegevens over het personeelsbestand en het bedrijfsbeleid. De gemiddelde waarden van de indicatoren op COROP-regio zijn weergegeven in figuur 1. In de figuur worden tevens de waarden van de hoogst en laagst scorende COROP-regio weergegeven.

De twaalf kenmerken van werknemers geven in de meeste gevallen het percentage werknemers aan dat het (helemaal) eens is met één of meer stellingen betreffende het onderwerp. Uitzonderingen hierop zijn de indicatoren willen en kunnen doorwerken (waar de gemiddelde leeftijd is aangegeven), het hebben gevolgd van scholing in de afgelopen twee jaar (\% ja) en korter dan vijf jaar werkzaam zijn bij de huidige werkgever (\% ja). De vijf werkgeverskenmerken zijn anders opgebouwd. Het aandeel personeel dat voldoende is toegerust voor de uitvoering van het werk, betreft het gemiddelde percentage dat door de werkgevers is opgegeven. De tevredenheid over de leerbereidheid van het personeel betreft het percentage werkgevers dat in (zeer) sterke mate tevreden is. Het belang van doorwerken tot de pensioengerechtigde leeftijd wordt weergegeven als het percentage werkgevers dat aangeeft dit belangrijk te vinden voor de personele bezetting. Innovatie van het productieproces omvat het percentage werkgevers dat in de afgelopen twee jaar innovaties heeft doorgevoerd in het productieproces. Het laatste kenmerk geeft het percentage werkgevers weer dat maatregelen heeft getroffen om langer doorwerken mogelijk te maken. 


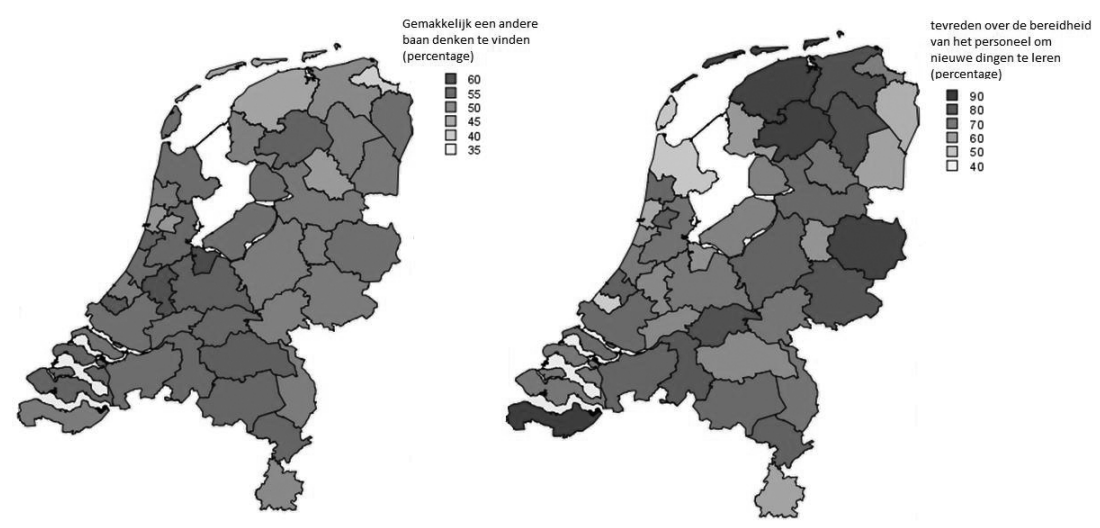

Figuur 2 Het percentage werknemers dat denkt gemakkelijk een andere baan te vinden (links) en het percentage werkgevers dat tevreden is over de bereidheid van het personeel om nieuwe dingen te leren (rechts); indeling naar COROP-regio (bron: NEA 2012 en WEA 2012)

\section{Regionale verschillen in duurzame inzetbaarheid}

Het reikt voor deze notitie te ver om alle afzonderlijke DI-indicatoren grafisch weer te geven. In figuur 2 worden daarom als voorbeeld twee indicatoren met een aanzienlijke spreiding weergegeven voor de COROP-gebieden. Het gaat om één werknemerskenmerk: het aandeel werknemers dat gemakkelijk denkt een andere baan te vinden (links). En één werkgeverskenmerk: het aandeel werkgevers dat tevreden is over de leerbereidheid van werknemers (rechts). Uit de linker figuur valt op te maken dat werknemers in de regio's in de Randstad vaker denken gemakkelijk een andere baan te vinden dan werknemers in Noord- en Oost-Nederland. In de rechter figuur valt te zien dat het aandeel werkgevers dat tevreden is met de leerbereidheid van werknemers hoog is in Friesland, Twente/ Oost-Gelderland en Zeeuws-Vlaanderen, terwijl dit aandeel lager is in de regio's Oost-Groningen, Zuidoost-Drenthe en de Kop van Noord-Holland.

\section{De invloed van de controlevariabelen op de regionale verschillen in duurzame} inzetbaarheid

Vervolgens kan de vraag worden gesteld in welke mate deze regionale verschillen verklaard worden door andere regionale kenmerken van de werknemers en bedrijven, zoals de opbouw van leeftijd, geslacht en opleidingsniveau van de werknemers, en bedrijfsgerelateerde kenmerken zoals sector en bedrijfsomvang. Daarnaast kan de arbeidsmarkt in de regio's van invloed zijn. Een krappe regionale arbeidsmarkt bijvoorbeeld kan ervoor zorgen dat werknemers zich relatief weinig zorgen maken over hun positie op de arbeidsmarkt. Een ruime regionale arbeidsmarkt kan ertoe leiden dat deze zorgen toenemen en de motivatie bij werknemers 
vermindert om nieuw werk te zoeken. Om te onderzoeken of de regionale verschillen per indicator van het DI-profiel verklaard worden door andere regionale kenmerken, zijn kenmerken uit de NEA, WEA en arbeidsmarktcijfers van het UWV (2013) geaggregeerd naar COROP-niveau. Deze kenmerken zijn als onafhankelijke variabelen toegevoegd aan regressiemodellen voor elke afzonderlijke indicator van het DI-profiel. Tabel 1 geeft aan welke van deze factoren (mede) van invloed zijn op de zeventien indicatoren van duurzame inzetbaarheid. Omdat het is berekend op basis van de verschillen in de veertig COROP-regio's, moeten zij dus ook worden geïnterpreteerd als factoren die mede van invloed zijn op de regionale verschillen in duurzame inzetbaarheid.

De resultaten laten zien dat de verschillende kenmerken van duurzame inzetbaarheid op regionaal niveau een wisselende samenhang vertonen met andere regionale kenmerken en dat de getoetste modellen sterk verschillen in hun verklaringskracht. De eerste twaalf werknemerskenmerken in de tabel kunnen worden onderverdeeld in kenmerken van de werknemers zelf (persoonskenmerken), kenmerken van de bedrijven waar ze werken en kenmerken van de arbeidsmarkt. Dat levert een soms wat meer en soms wat minder herkenbaar plaatje op wat betreft de regio's die op het gebied van duurzame inzetbaarheid succesvol en minder succesvol zijn.

Bij de kenmerken van de werknemers blijkt dat het tot een gemiddeld hogere leeftijd willen en kunnen doorwerken vooral voorkomt in regio's waar de gemiddelde leeftijd van de werknemers al hoog is (alleen het willen, niet het kunnen), waar relatief weinig middelbaar opgeleide werknemers werken en waar gemiddeld veel werknemers in kleine bedrijven werken. In regio's met relatief veel kleine bedrijven en een kleine flexibele schil geven veel werknemers aan dat ze een gemiddeld goede gezondheid hebben. Het lijkt hier vooral te gaan om werknemers in regio's met veel bedrijven in de secundaire sectoren, zoals de handel en de horeca. In regio's waar werknemers aangeven dat er een goede werk-privébalans is, is de gemiddelde leeftijd van werknemers laag (veel werknemers met zorg voor kinderen), werken minder werknemers met een allochtone afkomst en werken veel werknemers in grote bedrijven. 


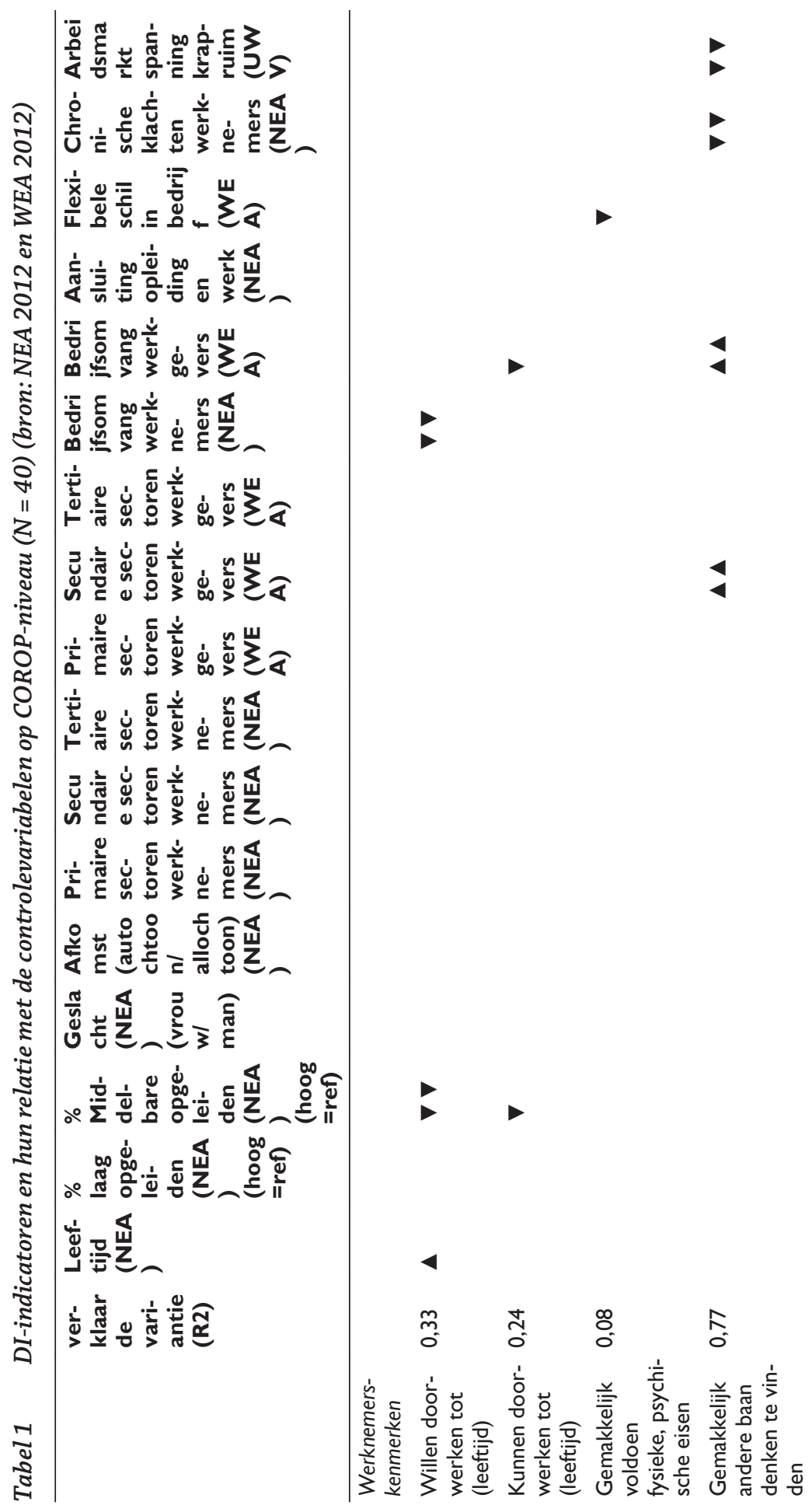




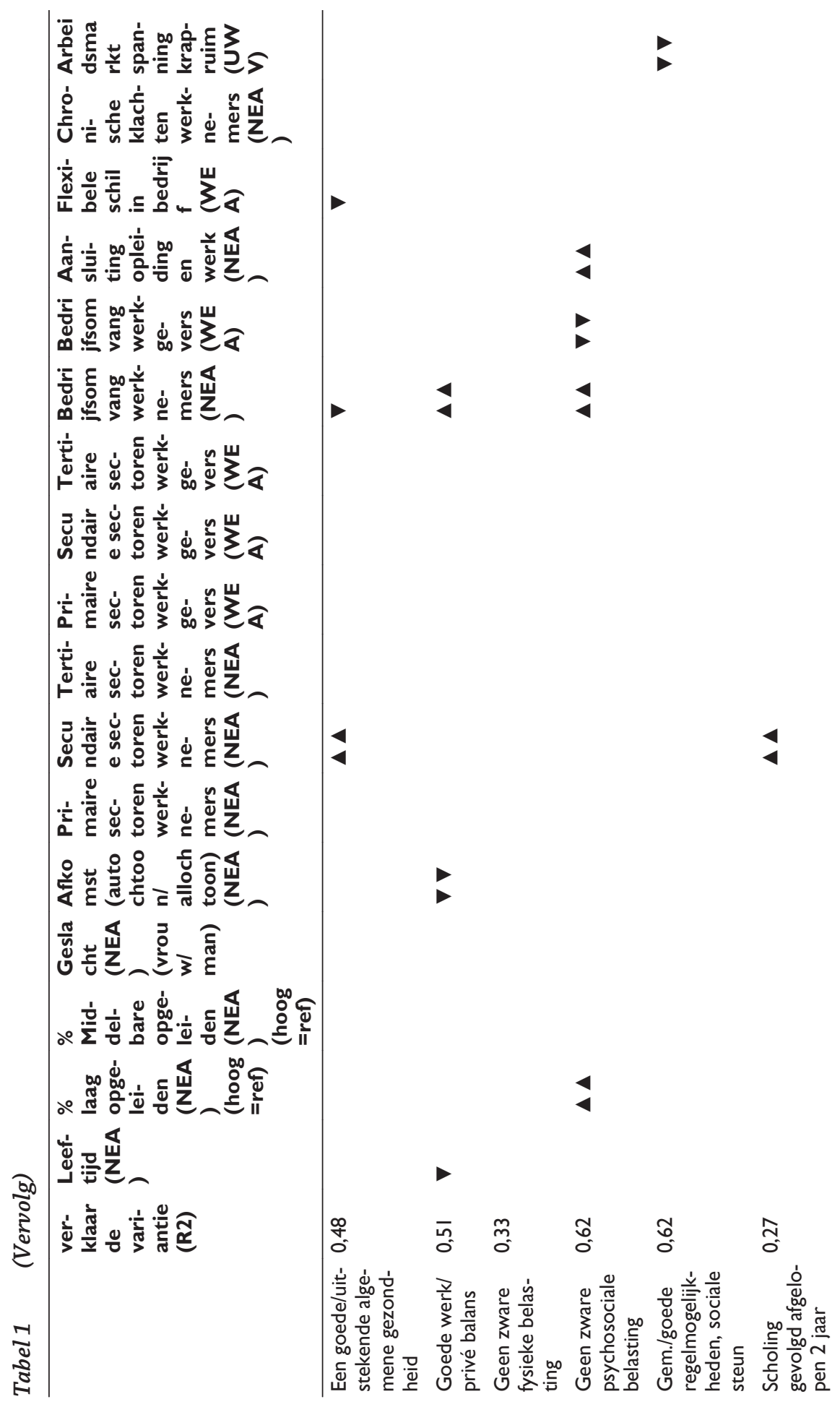




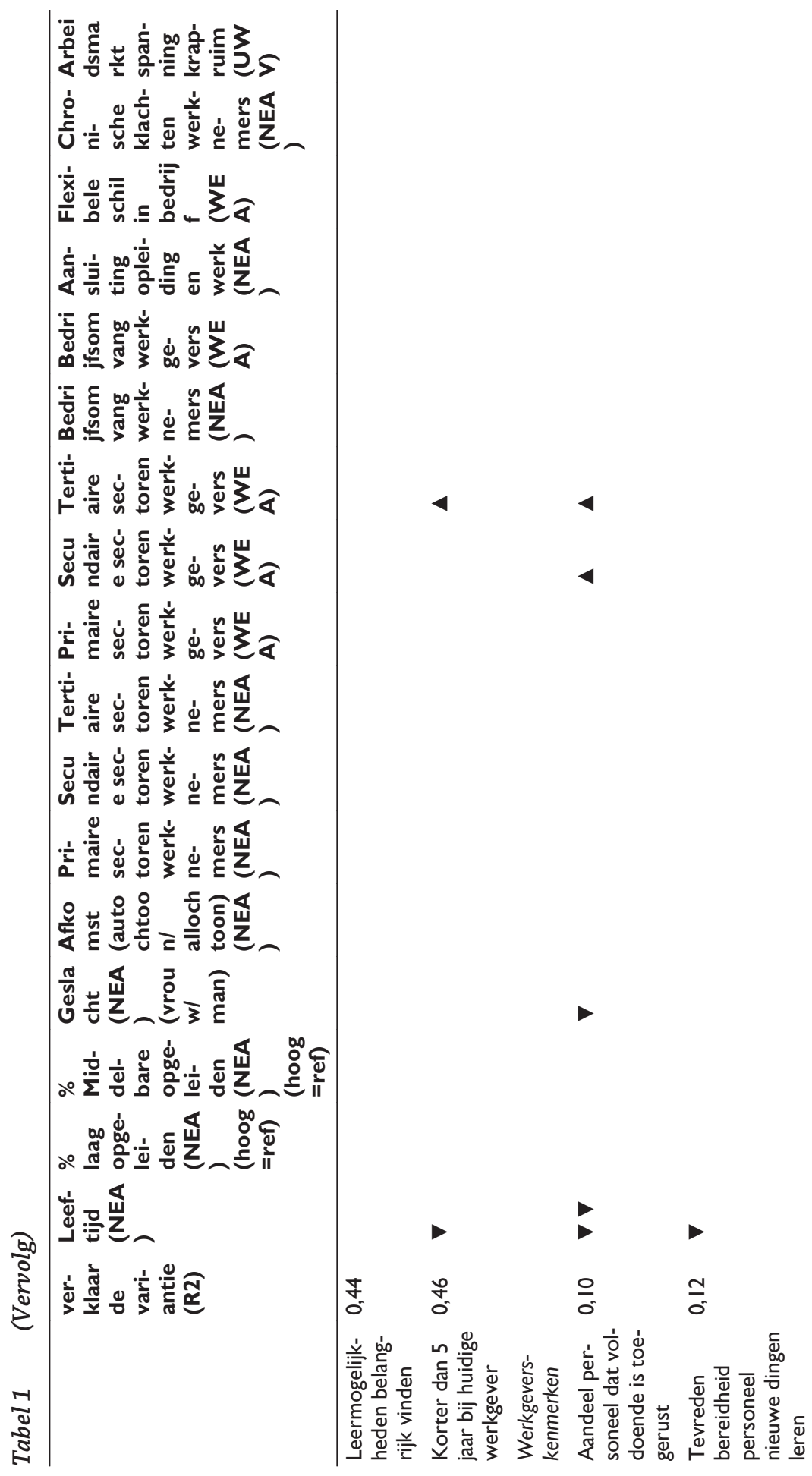




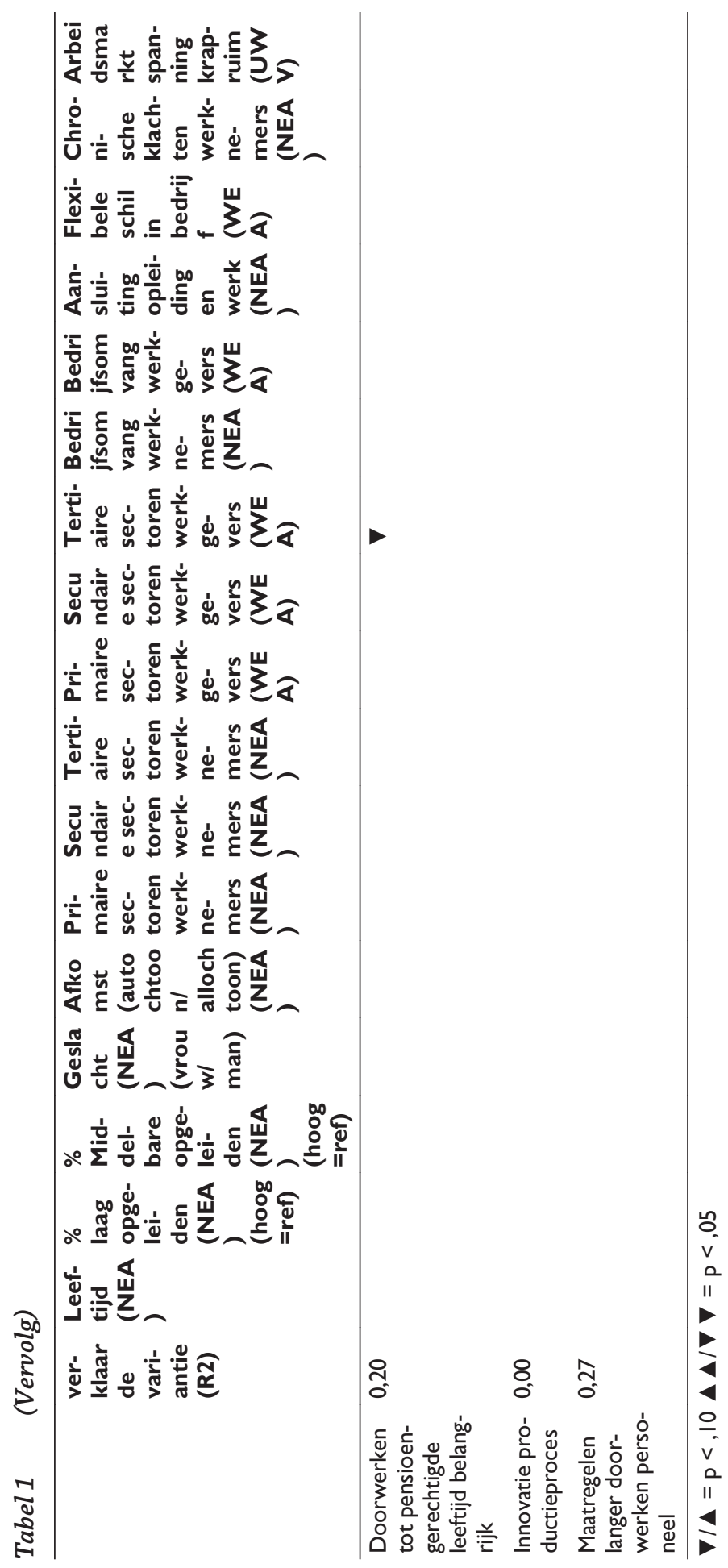


Bij de kenmerken van de bedrijven blijkt dat in regio's met bedrijven met een relatief kleine flexibele schil ook vaak werknemers werken die aangeven dat ze gemakkelijk kunnen voldoen aan de fysieke en psychische eisen van het werk. In regio's waar werknemers aangeven dat er relatief weinig psychosociale belasting is, werken veel werknemers in kleine bedrijven, hoewel er ook veel relatief grote bedrijven zijn, en is de aansluiting tussen opleiding en werk relatief goed. Er werken relatief veel werknemers met een laag opleidingsniveau.

Bij de kenmerken van de regionale arbeidsmarkt blijkt dat werknemers wat gemakkelijker een andere baan kunnen vinden in regio's met veel bedrijven in de secundaire sectoren (handel en horeca), met relatief veel grote bedrijven en regio's met een geringe arbeidsmarktspanning. Het gaat hier ook om regio's waar werknemers aangeven dat ze gemiddeld weinig chronische klachten en/of aandoeningen hebben. Bedrijven hebben daar ook werk met goede regelmogelijkheden en sociale steun en werknemers werken er vaak in bedrijven in secundaire sectoren en waar ze relatief vaak scholing hebben gevolgd in de afgelopen twee jaar. Vooral jonge werknemers lijken daar relatief goede kansen te hebben wat betreft het krijgen van een nieuwe baan (relatief veel werknemers die korter dan vijf jaar bij de huidige werkgever werken) en in de tertiaire sectoren.

Bij de onderste groep van vijf werkgeverskenmerken gaat het vooral om het succes van bedrijven wat betreft duurzame inzetbaarheid. In regio's waar veel oudere werknemers werken, geven bedrijven aan dat het aandeel van het personeel dat voldoende is toegerust voor de eisen die het werk stelt, gemiddeld lager is en dat ze niet tevreden zijn over de bereidheid van het personeel om nieuwe dingen te leren. Daar werken relatief veel mannen en veel werknemers in de secundaire en tertiaire sectoren. In regio's met veel tertiaire sectoren vinden veel bedrijven het doorwerken tot de pensioengerechtigde leeftijd minder belangrijk. Over het algemeen valt op dat de verklaarde variantie voor de modellen met werkgeverskenmerken lager uitvalt dan bij de werknemerskenmerken. Dit houdt in dat de onafhankelijke variabelen de spreiding van deze kenmerken minder goed verklaren en dat er mogelijk andere kenmerken zijn die de regionale verschillen verklaren. Hoewel de aangetroffen verbanden statistisch significant zijn, is enige voorzichtigheid bij de interpretatie geboden.

De relaties met de andere regionale kenmerken zorgen ervoor dat de regionale verschillen in het DI-profiel enigszins afgezwakt worden. Het is echter niet zo dat dan alle verschillen verdwijnen. Dat blijkt ook uit de eerste kolom van tabel 1 , die de verklaarde variantie geeft. De ratio's (percentages) variëren sterk, maar blijven vaak onder de $50 \%$, wat aangeeft dat er nog veel ruimte overblijft voor andere verklaringen.

Ter illustratie worden de beide kenmerken uit figuur 2 nogmaals weergegeven, maar nu statistisch gecorrigeerd voor de controlevariabelen. Deze worden weergegeven in figuur 3. In deze figuur is te zien dat de regionale verschillen voor beide kenmerken iets kleiner worden, maar zeker niet verdwijnen. Hoewel $77 \%$ van de variantie verklaard wordt door de controlevariabelen blijft het aantal personen dat gemakkelijk een andere baan denkt te vinden in zowel de gecorrigeerde als de ongecorrigeerde variant significant lager in de COROP-regio Delfzijl en omgeving (respectievelijk 39,8 en 41,1\%). Dit aantal ligt in de ongecorrigeerde gegevens 


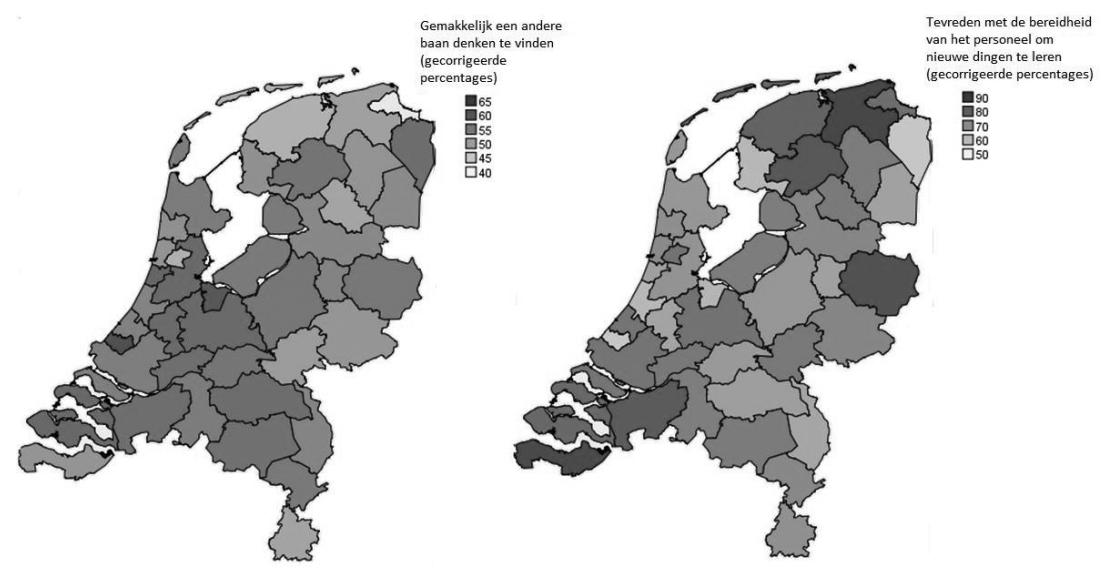

Figuur 3 Het percentage werknemers dat denkt gemakkelijk een andere baan te vinden (links) en het percentage werkgevers dat tevreden is over de bereidheid van het personeel om nieuwe dingen te leren (rechts); gecorrigeerd voor regionale kenmerken; indeling naar COROP-regio (bron: NEA 2012 en WEA 2012)

hoger in de COROP-regio Gooi en Vechtland (61,1\%), terwijl dit in de gecorrigeerde gegevens hoger ligt in de COROP-regio Delft en Westland (60,8\%). De controlevariabelen verklaren $12 \%$ van de variantie van de tevredenheid van werkgevers met de leerbereidheid van het personeel, maar ook hierbij neemt de spreiding af. In de ongecorrigeerde versie ligt deze significant lager in de COROPregio's de Kop van Noord-Holland (49,6\%) en Delft en Westland (48,6\%). In de gecorrigeerde versie verdwijnt dit verschil en ligt de tevredenheid juist statistisch hoger in de COROP-regio's Overig Groningen (85,7\%) en Zeeuws-Vlaanderen (85\%).

\section{Conclusies}

Moet de bevordering van duurzame inzetbaarheid nu op regionaal niveau aangepakt worden? Om deze vraag te beantwoorden zijn indicatoren van duurzame inzetbaarheid aan werkgevers- en werknemerszijde onderzocht en vergeleken tussen de veertig COROP-regio's. De resultaten laten zien dat duurzame inzetbaarheid regionale verschillen vertoont en dat deze verschillen slechts voor een deel kunnen worden verklaard door regionale verschillen in de samenstelling van de werknemersgroepen, de bedrijven die er actief zijn en de arbeidsmarkt. De regionale verschillen worden echter niet volledig verklaard door deze kenmerken. Dit houdt in dat andere, niet onderzochte factoren eveneens van invloed zijn op duurzame inzetbaarheid. 
Op basis van de bevindingen lijkt één landelijk duurzame inzetbaarheidsbeleid niet raadzaam. De bevindingen pleiten eerder voor een tweeledige aanpak waarin landelijk en regionaal beleid in elkaars verlengde liggen. Het landelijk beleid kan zich dan richten op de (wettelijke) kaders van een duurzaam inzetbare beroepsbevolking. Deze kaders omvatten dan nationale richtlijnen en wetgeving en zouden in eerste instantie werkgevers en werknemers in staat moeten stellen om samen tot duurzame oplossingen te komen. Het kan daarbij gaan om voorlichting, opleidingsrechten en -plichten, enzovoort. Op lokaal en regionaal niveau kan het beleid vervolgens worden vertaald naar regionaal werkbare constructies, waarmee recht wordt gedaan aan de specifieke regionale samenstelling en omvang van de beroepsbevolking en de economische structuur. Bovendien kan de naleving van de nationale kaders op lokaal of regionaal niveau worden gecontroleerd. Met het oog op komende decentralisaties omtrent arbeidsmarktbeleid komt ook de verantwoordelijkheid voor duurzame inzetbaarheid steeds meer te liggen bij gemeenten en UWV. Landelijk beleid kan hier een beknellende uitwerking hebben op het beleid van de lokale overheden, als zij te veel voor voldongen feiten komen te staan. In een dergelijke constructie is een goed inzicht in de regionale situatie bovendien onontbeerlijk.

Met zowel de constatering dat er grote regionale verschillen bestaan in duurzame inzetbaarheid als het besef dat arbeidsmarktbeleid in toenemende mate wordt gedecentraliseerd, lijkt het antwoord op de vraag of duurzame inzetbaarheidsbeleid een regionale aangelegenheid is, helder. Door oog te hebben voor regionale verschillen en regionale en lokale overheden de ruimte en middelen te bieden om regionaal toegespitst beleid te voeren, kunnen de doelstellingen van het nationale duurzame inzetbaarheidsbeleid het meest gericht worden nagestreefd.

\section{Literatuur}

Hooftman, W., Klauw, M. van der, Klein Hesselink, J., Terwoert, J., Jongen, M., Kraan, K., Wevers, C., Houtman, I. \& Koppes, L. (2012). Arbobalans 2011: Kwaliteit van de arbeid, effecten en maatregelen in Nederland (Hoofdstuk 6: Duurzame inzetbaarheid). Hoofddorp: TNO.

Inspectie SZW. (2013). Regierol gemeenten bij regionaal arbeidsmarktbeleid. Den Haag: Ministerie van Sociale Zaken en Werkgelegenheid.

Koppes, L.L.J., Vroome, E.M.M. de, Mars, G.M.J., Janssen, B.J.M., Zwieten, M.H.J. van \& Bossche, S.N.J. van den. (2013). Nationale Enquête Arbeidsomstandigheden 2012: Methodologie en globale resultaten. Hoofddorp: TNO.

Kraan, K., Wevers, C., Geuskens, G. \& Sanders, J. (2011). Monitor Duurzame InzetbaarheidResultaten 2010 en Methodologie, Hoofddorp: TNO.

Oeij, P.R.A, Vroome, E.M.M. de, Kraan, K., Goudswaard, A. \& Bossche, S.N.J. van den. (2013). Werkgevers Enquête Arbeid 2012: Methodologie en beschrijvende resultaten. Hoofddorp: TNO.

UWV. (2013). Spanningsindicatoren arbeidsmarkt naar beroepsniveau en gemeente, kwartaal 4 2012. Beschikbaar op www.werk.nl/werk_nl/arbeidsmarktinformatie/tabellen. 